\title{
Management Model on Industrial-Class Vocational Boarding Schools (Pesantren) to Develop Graduates with Character and Competence
}

\author{
Wirawan Sumbodo \\ wirawansumbodo@mail.unnes.ac.id
}

Mechanical Engineering, Faculty of Engineering, Universitas Negeri Semarang

\begin{abstract}
The research aims to finding a management model on industrial-class vocational boarding school used project-based and teaching-collaboration learning; increase character and competence students of vocational high schools based on Pesantren; Improving student competency vocational high schools based on Pesantren. The research method used is Research and Development. The research subjects of SMK Roudlotul Mubtadiin Balekambang, Jepara, Indonesia in the competence of Computer Network Engineering (CNE) and Audio-Video Engineering (AVE). This article found that in learning in vocational competencies of different skills but still in the same field of science clumps can be carried along by using project-based learning and teaching-collaboration learning. Project-based learning can enhance the industrial character (critical thinking, creativity, collaboration, and communication). Competency improvement includes computer and basic network, broad-based network technology, computer systems, basic programming, workbenches, engineering drawing; basic electrical and electronics. The study is limited to the competence of Computer Network Engineering (CNE) and Audio-Video Engineering (AVE) on vocational boarding schools based on Pesantren. Collaboration allows other competency skills in a clump of different sciences but in the same school. Need research on a regular vocational high school.
\end{abstract}

Keywords Management model, Characters, Boarding school, Teaching-collaboration, Project-based learning.

\section{Introduction}

The Government has made efforts to improve the education system through the revitalization of Vocational High School (VHS). Revitalization of Interest VHS follows Instruction number 9, 2016. The Minister of Education and Culture instructs to enhance and harmonize the vocational curriculum by with the requirements of competence of graduates so that graduates have the knowledge or competitive attitudes. Besides, with the revitalization of VHS is to change the paradigm that was once only encountered to develop graduates without regard to labor market needs to change the paradigm of searching for anything related to the labor market from working culture 
and competencies required in the labor market, changing the learning of supply-driven to demanddriven, setting up vocational graduates adaptable to changes in the world (Hendarman, et all, 2016).

One of VHS-based boarding school is VHS Roudlotul Mubtadiin Balekambang, Jepara. Pesantren is an institution that can be said is a form of the natural process of development of the national education system. Pesantren education institutions have a strategic position in the world of education in Indonesia. As one form of education, schools have a special place in front of the public. This is because schools have greatly contributed to the life of the nation and the cultural development of society (Mas'udi, 2015).

The school's vision is to become a superior educational institution, creative, innovative, global perspective and character with the teachings of Islam rest on the style of Ahlus Sunnah Wal Jama'ah. A school will be able to achieve the vision, mission, and purpose if all components of the school can run the respective roles well. So is the role of a teacher.

Teachers as educators and employees as educators require any change in the character to fit the needs of students and industry. This is to show the teacher's philosophy obeyed, reliable and replicable example. Teachers in the profession underwent 4 ON should apply: (a) visiON, which means that teachers must set a vision for teaching; (b) actiON, which means that teachers must move with the learning method of interactive and fun; (c) passiON, which means that teachers have to work with the heart; (d) CollaboratiON, which means that teachers must establish collaboration with the industry.

Along with achieving these educational goals, the teacher as an educator has an important role in it. Based on interviews with the Principal of SMK Roudlotul Mubtadiin Balekambang, there is a lack of human resources (HR) for teachers. The lack of teacher's human resources will certainly hinder the process of achieving educational goals that have been set previously.

From the data taken using a questionnaire that vocational students' learning motivation Mubtadiin Roudlotul is fairly low. the learning motivation of boarding school-based vocational students the first is religion (akhlaq) 66\%, the second is learning 14\%, work 6\%, coercion $6 \%$, and the other $2 \%$.

In an essence graduates of vocational students should be absorbed into the industry. However, because vocational schools based Mubtadiin Roudlotul, industrial culture is still low even less applied in the schools.

The characteristics that now includes: kind, humble, disciplined, no smoking, lazy, arrogant, polite, patient, diligent, honest, confident, thriving, thrifty, wise, communicative, smart, naughty, creative, assertive, independent, socialist, responsible, cool, hard work, innovative. Having analyzed the existing main character researchers reduction into characters. The existing conditions of the students' characters are disciplined $41 \%$, honest $20 \%$, lazy $12 \%$, patient and independent $6 \%$, communicative smart and naughty $4 \%$, and others $3 \%$

Skills students to communicate, collaborate, think critically and creatively in Indonesia is still less competent and that they should continue to do so improved, especially for science subjects (Zubaidah,2016; Saputri et al., 2017; Siswanto et al., 2014; Pratiwi and Muslims, 2016; Yuliati, 2017). Skills someone a person can influence the success and success in work.

In addition to a lack of human resources and low motivation of students, to improve student learning outcomes need to be a medium of learning in the learning process. During this learning, media availability is still low for the students to carry on the eyes learning productive practices. Study result in less than the maximum. 
We have now entered the era of industrial 4.0. where education has a new challenge, namely the character and competence. 4.0 industrial character needs in this course should be a concern on the part of graduates of vocational schools to be able to follow the development of the era. The skills required for Industry 4.0 are many and varied. Characteristics of the industrial revolution 4.0 is marked by a variety of applied technology (applied technology), as advanced robotics, artificial intelligence, internet of things, virtual and augmented reality, additive manufacturing, as well as distributed manufacturing as a whole is able to change the pattern of production and business models in various industrial sectors.

Four main categories were needed in the industrial era 4.0 (a) technical competence as advanced knowledge, understanding the process, technical skills, etc., (b) the methodological competencies including creativity, entrepreneurial thinking, problem-solving, conflict resolution, decision making, analytical skills, research skills, and orientation efficiency. (c) social competencies such as intercultural skills, language skills, communication skills, networking skills, ability to work in teams, the ability to compromise and cooperate, the ability to transfer knowledge and leadership skills. (c) the personal competencies which include flexibility, ambiguity tolerance, motivation to learn, the ability to work (Leinweber, 2013). The graduate skills gap widely discussed in several studies. Many studies that present how to prepare students to have skills needed in the working world (Yunus and Li, 2005; Andrews and Higson, 2008)

So that learning becomes more efficient, improving the character and skills of students, need to model appropriate learning for maximum results. In this case the use of project-based learning research and teaching collaboration in the learning process in vocational Roudlotul Mubtadiin Balekambang, Jepara.

Based on the problems the purpose of this study is

1. Finding a management model on industrial-class vocational boarding school used projectbased and teaching-collaboration learning,

2. Increase character and competence students of vocational high schools based on Pesantren,

3. Improving student competency vocational high schools based on Pesantren.

\section{Theoretical background}

\section{A vision VHS}

Educational purposes related to school vision to be achieved in line with expectations. Vision is the ultimate goal of the school is achieved in the long term. While the mission is the next mediumterm objective specified in the usual school goals to be achieved each year school operations (Pratiwi and Muslims, 2016).

A vision of VHS Roudlotul Mubtadiin Balekambang Jepara is Becoming a superior educational institution, creative, innovative, global perspective and character with the teachings of Islam on the style of Ahlus Sunnah Wal Jama'ah. The mission of vocational Roudlotul Mubtadiin Balekambang Jepara include: (a) Providing schools that excel in academic and non-academic; (b) Carrying out the learning process to develop the potential of the learners; (c) Implement educational activities to foster the creativity of learners; (d) Organizing - innovative activities; (e) Implement education 
based on the development of character; (f) To prepare graduates who have the entrepreneurial spirit and responsible with the social environment; (g) To prepare graduates who understand and obey the teachings of his religion.

The purpose of the school as part of a national educational goal is to improve the intelligence, knowledge, personality, character, and skills to live independently and to follow further education. In more detail, the purpose of Roudlotul Mubtadiin Balekambang Jepara is as follows (a)To develop graduates who are competent and certified, (b) Improving the quality of competency-based learning and production, (c) Preparing students to be able to develop a professional attitude, adapt to the environment, independent, persevering in competition, disciplined and tenacious, (d) Improving the quality of teachers and professionals, (e) Increase the satisfaction of the community to obtain services appropriate education and vocational training skills program, (f) Be consistent in the implementation of activities, quality control and quality assurance of school, (g) Improving the welfare of the school community.

\section{Industrial Era 4.0 and challenges}

In the roadmap Making Indonesia 4.0, one of the program priorities is improving the quality of Human Resources (HR). Therefore, talent is the key or important factor for the success industrial 4.0 implementation. HR is essential to achieve the success of Indonesian Making 4.0. Indonesia plans to overhaul the education curriculum with a greater emphasis on STEAM (Science, Technology, Engineering, the Arts, and Mathematics), aligning the national curriculum to the needs of industry in the future. Indonesia will cooperate with industry and foreign governments to improve the quality of a vocational school while improving global workforce mobility programs to take advantage of the availability of human resources to speed up the transfer capability (Indonesian ministry of industry, 2018).

Character is the key to success (Oemary, 2015) because the character is the main capital and important for the progress of individuals and the nation. Pesantren as one of the institutions that can shape the character of the students. Character education is an investment process essential values in children through a series of learning activities and mentoring to students as individuals capable of understanding, experience, and integrate value into core values in education that lived into his personality. Character education as well as an effort to educate children to make decisions wisely and put it into practice in everyday life, so that they can make a positive contribution to the environment (Kholis, 2012). A nation that has a strong character usually grows and the more advanced and prosperous (Saptono, 2011).

\section{Character Education}

Education is one of the factors that determine and influence social change. Through education, it's expected to produce the next generation has a strong character to receive the baton of leadership of the nation. Unfortunately, many parties considered that such character is actually getting hard to match school students. Many of those involved in the brawl, drugs and so on. Thus sobering circumstances educators to develop character education (Zuhry, 2011).

Character education certainly has a strategy in implementing universally, that is, through the process of the 5 pillars of formation, The first pillar: Moral Acting by way of habituation and culture, Second pillar: teaching knowledge of good values (moral knowing), The third pillar: Moral feeling and loving; Feeling and loving well, Fourth Pillar: Moral Modeling of the Neighborhood, Fifth 
Pillar: Repentance of all sins and unprofitable things is possible (even innocent) by performing martyrdom, tahalli, and tajalli (Pratama, 2019).

Early childhood is a critical period for the formation of one's character. The methods of character education in pesantren are: (a) Exemplary Method, (b) Habitual Method, (c) Method of Giving Advice, (d) Motivation Method, (e) Persuasion Method, and (f) Story Method (Nofiaturrahmah, 2014 ).

\section{Competence and Curriculum}

Many research disciplines, such as Psychology, Education, Management, Human Resources Information System has been studying the concept of competency. Various researchers gave different definitions over the years and led to ongoing debates (Deist and Winterton, 2005). In today's educational world of education, competence is required especially when it comes to measuring the output and results of the learning process. In the sense that competence is regarded as keywords in education today (Gagnon, 2009).

The first definition is competence as "the basic characteristics of a person, which results in effective performance and/or excel in the job (Klemp, 1980). Competence basically behavior such as personality or intelligence, and can be taught through learning and development. The Functional approach focuses on competence as a prerequisite to successfully fulfill the task by limiting the time period for the skill competencies and skills required to perform the task (Straka, 2004). Competence as a collection of individual competence required of individuals - and the necessary organizational competencies at the organizational level to achieve the desired results.

Competence is defined as the willingness and ability of the individual to behave in the professional, social, and personal situations in an appropriate manner and considered, and to display individual and social responsibility. Competence to act is displayed in the dimension of professional competence, human competence, and social competence. Furthermore, professional competence describes the readiness and ability, on the basis of specific knowledge and ability to solve tasks and problems in a targeted manner, precise, methodical and independent and to evaluate the results (Straka, 2007; Bukit, 2014). Competence is defined as a description of the skills, knowledge, and attitudes necessary to achieve effective performance in the job. Competence is also made up of personalities, motivations, attitudes, and values (Prosser and Quigley, 1950).

In Asia the education system, there is a belief that rote learning and train students in the academic context to better prepare graduates for the workplace with the performance test are regarded as part of the almost necessary and non-negotiable of education (Teng and Turner, 2018).

In the Industrial Era 4.0 as at present, new skills are needed to face any kind of challenges that exist. There are two types of forms that emphasized skills to face the challenges in the Industrial Era 4.0 ie soft skills and hard skills.

Soft skills are skills or skills related to emotional intelligence, personality, social skills, and communication that characterize a person in interacting with others. Soft skills are required and stressed to face the industrial revolution 4.0 include communication, collaboration, critical thinking, problem-solving, and creativity and innovation (Bakrun, 2015).

Hard skill includes teamwork, project management, leadership, communication, creative thinking, and problem-solving, leading to the development of soft skills (Jones and Iredale, 2010; Fiala et al, 2014; Turner and Mulholland, 2017). 
There are three strategies to teach or practice the skills of critical thinking, namely: building categories finding the problem and enhancing the environment (conduciveness environment).

Creativity is a skill to discover, develop, design ideas/creative ideas to produce a product, and implement products that have been manufactured widely, and to evaluate the results of the implementation of activities that have been implemented for enhancement.

Communication skills or communication skills are skills for someone to be able to provide or deliver and receive an update in accordance with the facts. Three components that need attention so that communication is going well. These components are motivation, knowledge, and competencies.

According to Trilling et al, (2009) collaboration with others can be done by (a) demonstrate the ability to work effectively and to respect other individuals or groups; (b) exercise flexibility and willingness to help in making the decision together to achieve a common goal; (c) assumes ourselves that the responsibility for work collaboration and respected contribution made by each individual team member.

\section{Project-Based Learning}

Project-based learning is meaningful as project-based learning. Project-based learning is used in education Science, Technology, Engineering, and Math integrated and practical, to improve the understanding of the subject matter (Capraro and Slough, 2009; Redkar, 2012) A very effective production-based learning model was developed in the learning of students in increasing creativity and innovation (Ganefri, 2013). Project-based learning stresses education that give odds on the learning system based on learners/learners, collaboratively and integrate the real issues and practical, effective teaching in building knowledge and creativity (Indrawan et al, 2018).

\section{Collaboration}

The underlying principle of collaborative learning is based on the collaboration of its members. For the implementation of effective education for sustainable development, appropriate learning strategies need to be selected and used. Collaborative learning is an educational approach to teaching and learning that involves groups of students working together to solve a problem, complete a task, or create a product (Chandra, 2015).

The benefits of collaborative learning include (a) The development of higher-order thinking, oral communication, self-management, and leadership skills; (b) Promotion of the interaction of teachers and lecturers-industry; (c) The increase in student retention, self-esteem, and responsibility; (d) exposure and increase understanding of the diverse perspectives; (e) Preparation for social situations and real-life work.

\section{Methods}

This study uses research and development ( R \& D). The flowchart of this study are shown in Figure 1.
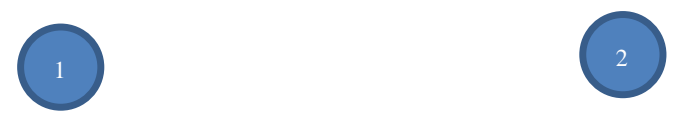

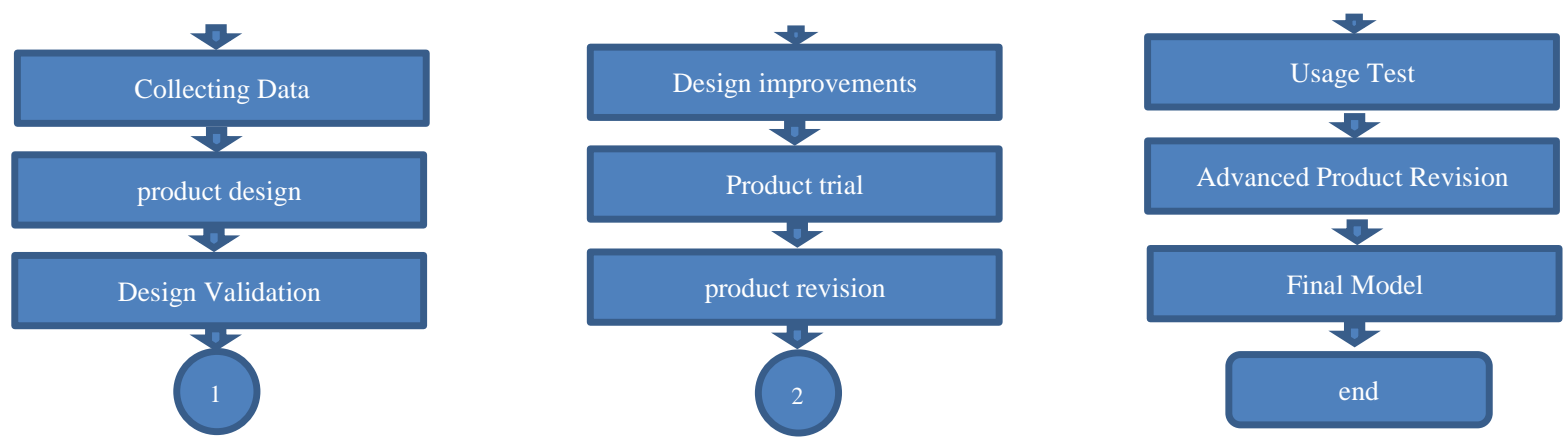

Figure 1. Research design

The research subject is class XI student of VHS boarding school based on the competency skills of Computer Network and Audio Video Engineering. The analysis used data using quantitative descriptive. Retrieving data using questionnaires, tests, projects, and FGD models. Data were taken on the odd academic year 2018/2019. The development management model is a model of the existing three phases, then corrected in accordance with the review of the literature to be a hypothetic model. Hypotetik models discussed in the FGD before trial limited. Furthermore, the model is validated by experts relating to the management and education character.

\section{Results}

Based on collected data, acquired the existing model of industrial-grade management model in vocational schools Roudlotul Mubtadiin Balekembang, Jepara. The existing models can be seen in Figure 2.

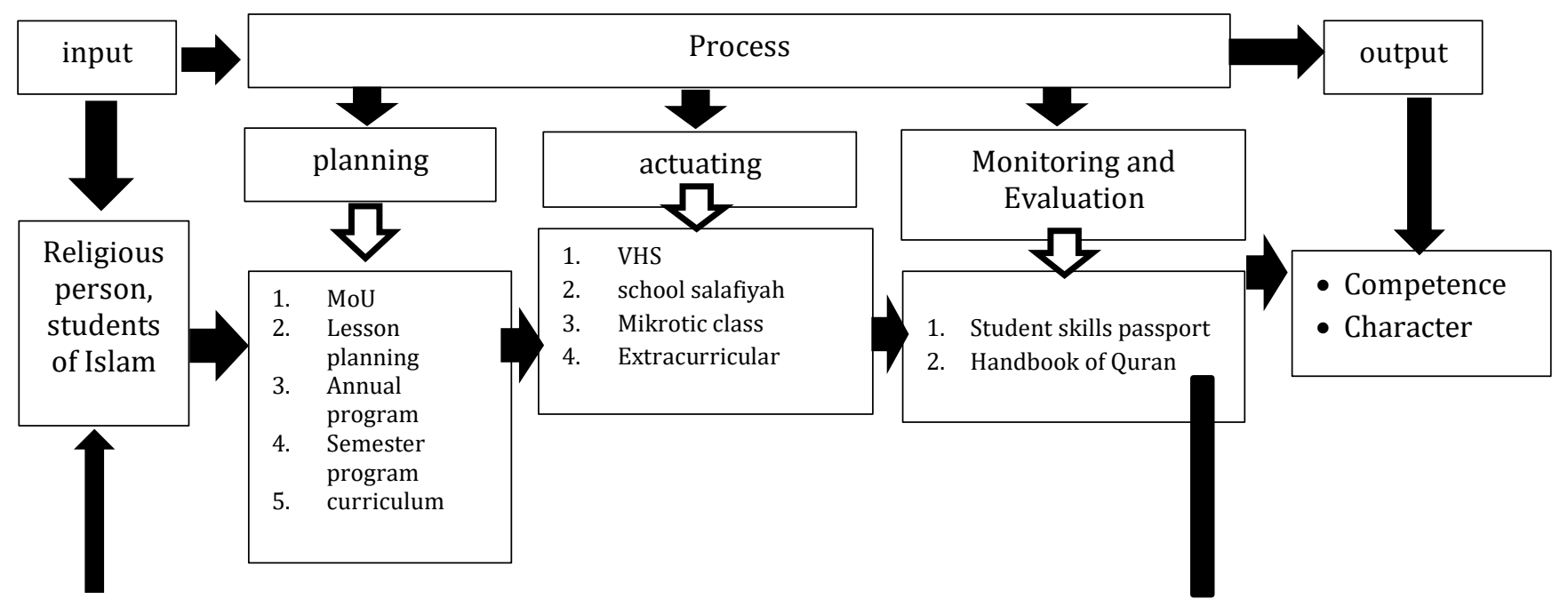


Figure 2. The exisiting management model industrial-class VHS based on Pesantren

Based on the research results show that there is an increased character on Roudlotul Mubtadiin Balekambang vocational students. Increased industrial character in students include critical thinking, creative and innovative, communicatiion, and collaboration.

With the literature review, the current model is improved so that industrial class management in pesantren-based vocational schools can run as expected. The results of these improvements were then discussed in a Focus Group Discussion by inviting experts in the education and pesantren-based vocational schools. Hypothetic model, the model has been improved later in the trial on competency skills of Lightweight Vehicle Engineering, Computer Network Engineering, and Audio-Video Engineering.

\section{Conceptual Model}

Project-based learning is used in education Science, Technology, Engineering, and Math integrated and practical, to improve the understanding of the subject matter (Capraro and Slough 2009; Redkar, 2012). Project-based learning stresses education that give odds on the learning system based on learners/learners, collaboratively and integrate the real issues and practical, effective teaching in building knowledge and creativity (Indrawan et al, 2018). A very effective productionbased learning model was developed in the learning of students in increasing creativity and innovation (Ganefri, 2013).

Characteristics of the Project-Based Learning includes (a) learning and decision making framework; (b) There is a problem and the solution that has not been predetermined; (c) Learners design a process to determine the outcome; (d) Learners are responsible for managing the information obtained; (e) There is a continuous evaluation; (f) Learners regularly look back at his work; (g) The final result in the form of the tested product quality.

The Conceptual Management Model of industrial class based in pesantren is shown in Figure 3. 


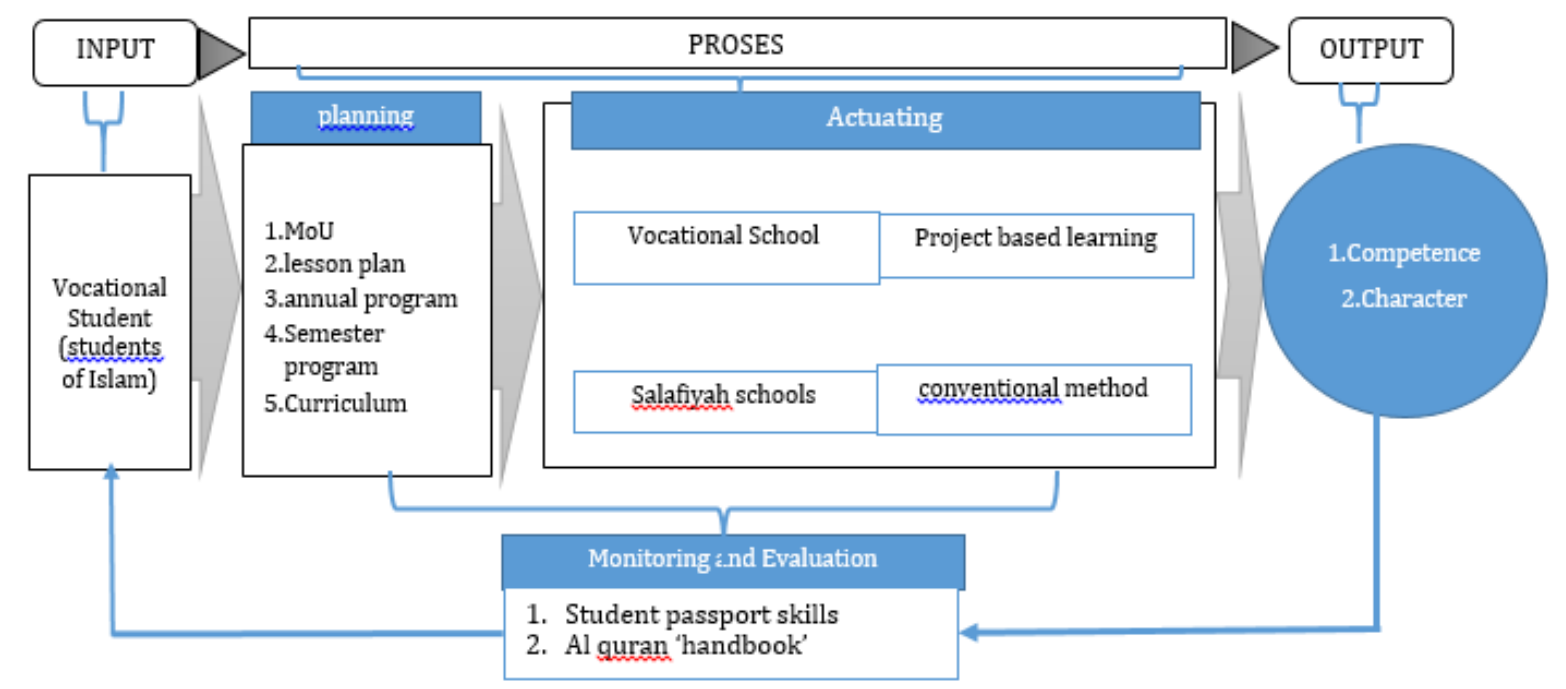

Figure 3. Design of Management Model on Industrial-Class Vocational Boarding Schools (Pesantren) to Develop Graduates with Character and Competence

Based on Figure 3, the input of the model is the vocational students. In the management model developed at the planning, phase consists of the MoU; lesson plan; Annual Program, Semester Program, and curriculum.

During the implementation phase of vocational students carry out two programs in schools, in the morning until noon vocational schools, and in the afternoon until evening Salafiyah school. On the implementation of vocational classes implemented project-based learning model (project-based learning) and teaching collaboration (collaborative learning is to deliver industry practitioners and lecturers from the fields of expertise as appropriate.

At the phase of monitoring and evaluation is by using the student's passport skill books and handbooks Qur'an. This handbook serves to monitor the development of the abilities and skills of the students or the students. Rasta is a term for the religious instruction of students in boarding school.

The output of this model is certainly the vocational graduates. Pesantren-based vocational school graduates expected. With hypothetic models is expected that students have the character of a critical forward-thinking, creative and innovative, communicative and collaborative in accordance with the demands of the industrial era 4.0. Expert validation is shown in Table 1.

Table 1. Summary of an assessment model

\begin{tabular}{clrrrr}
\hline \multirow{2}{*}{ No } & \multicolumn{1}{c}{ Score } & \multirow{2}{*}{ Average } \\
\cline { 3 - 5 } Rated aspect & \multicolumn{1}{c}{ Val 1 } & Val 2 & Val3 & \\
\hline 1 & Basic Model development & 3,789 & 4,000 & 3,842 & 3,877 \\
2 & $\begin{array}{l}\text { Management Model on Industrial-Class } \\
\text { Vocational Boarding Schools (Pesantren) to }\end{array}$ & 3,600 & 4,000 & 3,760 & 3,787
\end{tabular}




\begin{tabular}{|c|c|c|c|c|c|}
\hline 3 & Planning Component & 3,300 & 4,000 & 3,800 & 3,700 \\
\hline 4 & Planning Procedure & 4,000 & 4,000 & 4,000 & 4,000 \\
\hline 5 & Implementation Component & 4,000 & 4,000 & 3,667 & 3,889 \\
\hline 6 & Procedure for the implementation phase & 4,000 & 4,000 & 4,000 & 4,000 \\
\hline 7 & Evaluation Component & 3,000 & 4,000 & 4,000 & 3,667 \\
\hline
\end{tabular}

Val= Validator

Validation of the initial product (design) conducted by experts consisting of experts Evaluation, Media, and Pondok Pesantren. There are seven aspects that the validator and each aspect be broken down into indicators of assessment. Aspects that the validator is (1) Basic model development; (2) Model-based industrial-grade management Boarding School; (3) The planning component; (4) The procedures for planning management model; (5) implementation components; (6) Procedure for the implementation phase; (7) and evaluation component.

After that conducted Focus Group Discussion (FGD), and improvements made on the advice of expert judgment. The hypothetic model that has been fixed is shown in Figure 4. FGD followed by a lecturer in mechanical engineering, management, machining vocational school teachers, teachers of the boarding school. Suggested improvements in the model are at the implementation phase using project-based learning. Evaluation of learning outcomes of product produced. Rate character on the observation of learning and test knowledge of the character of the industry 4.0.

Draft development partnership management model based vocational industry has been carried out by the FGD participants stated clearly, easy to read and understand. Sequentially that the management principle used in vocational partnership with industry is the planning, implementation, and evaluation and apply the principles management, the model can be used by all VHS-based boarding school.

Thus, the management model of industrial-grade based boarding school is able to: (1) as an evaluation of the learning program productive, (2) as synchronization vocational curriculum with industry, (3) to develop learning resources by teachers and students, (4) to develop production unit, (5) shall be implemented to improve the competency of teachers and students, (6) to measure the competencies achieved by students, (7) to meet the needs of working in Business and Industry. Hypothetic the model is shown in Figure 4. 


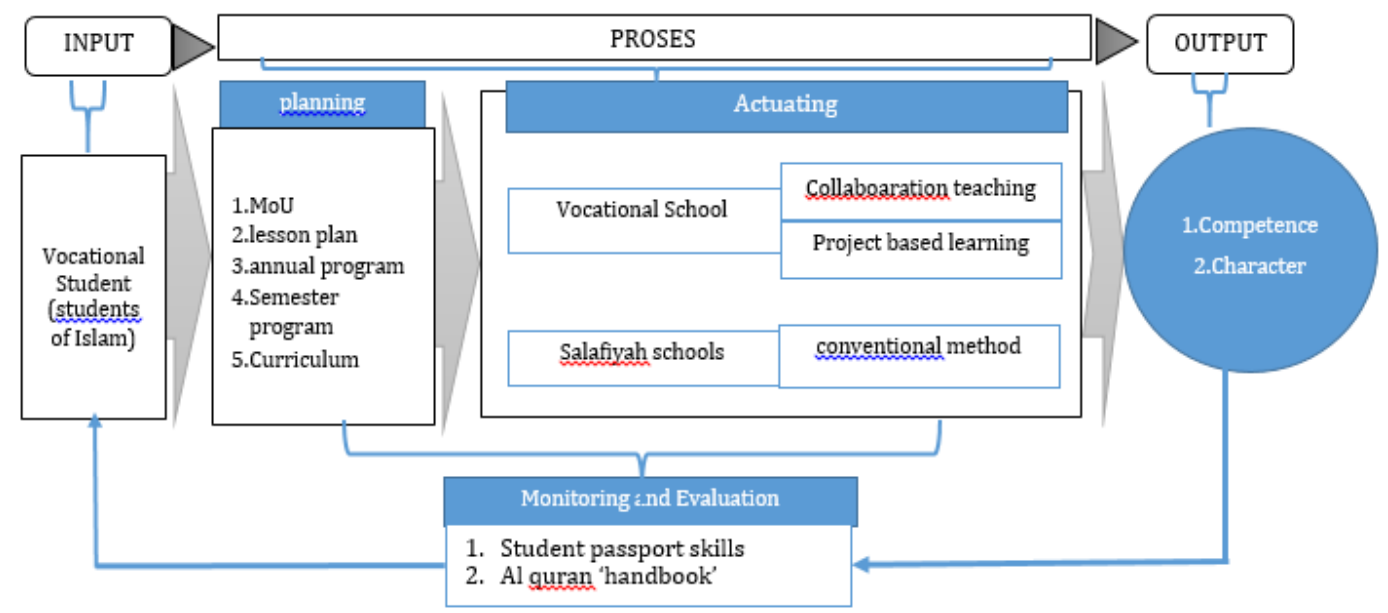

Figure 4. Model hypothetical of Management Model Industrial-Class Vocational Boarding Schools (Pesantren) to Develop Graduates with Character and Competence

Basic model development which is based on the concept of Project-Based Learning (PBL) is the link between VHS with industrial partners ranging from lesson plans, learning implementation, evaluation of learning and competency testing. The concept is combined with the model of the existing results of the preliminary study, then analyzed based on four principles, namely (1) the principle of management, (2) the principle of vocational education (Prosser \& Quigley 1950) can be used to analyze models of existing and (3) the principles of project-based learning, (4) the principle of assessment of learning outcomes VHS must use a project-based assessment methods.

Product assessment is an assessment of the learners' skills in applying knowledge in the form of a product at a certain time in accordance with the criteria established in terms of both the process and the outcome. Product assessment conducted on the quality of a product.

Rate product aims to (1) assess student skills in making certain products in connection with the achievement of learning objectives in the classroom; (2) assess the acquisition of skills as a requirement to learn the next skill; and (3) assess the ability of students to explore and develop ideas in designing and demonstrate innovation and creation.

An assessment project is an activity to determine the students' ability to apply their knowledge through the completion of a project instrument in the period or a specified time. An assessment project can be done to measure one or more of basic competencies in one or more subjects. An instrument in the form of a series of activities ranging from planning, data collection, organizing data, processing and presentation of data, and reporting.

An Assessment project aims to develop and monitor the student's skills in planning, investigating and analyzing the project. In this context, students can demonstrate their experience and their knowledge of a topic, formulate questions and investigate the topic through readings, tours, and interviews. Their activity can then be used to assess his ability to work independently or in groups. The product of a project can be used to assess the ability of students to communicate their 
findings to the appropriate shape, for example, through a visual presentation of the results display or written report.

\section{Trial Model}

The field trials conducted in vocational boarding school based on pesantren Roudlotul Mubtadiin Balekambang. In the pilot phase include planning implementation and monitoring and evaluation. In the planning phase to try to involve design learning with industry partners. Then from industry partners giving out advice for learning is project-based. The project award is to try to design and animate vehicles using wifi network-based microcontroller. Competence expertise to implement the automotive engineering, Computer and Network Engineering and Audio-Video Engineering

In the implementation phase of the project carried out in the late afternoon after a vocational school or after school Salafiyah at night. Implementation lasted for 2 months. Once the projects are carried out the evaluation. The results of the evaluation of the project show that the project is done successfully turn the vehicle (motorcycle) using smartphones connected to the wifi network at school. Monitoring is also carried out on the project. At the time of implementation students often work until late at night so in the morning when school students feel sleepy. Then the materials are scattered many practices.

After the limited field trials further, implement the FGD regarding learning outcomes obtained. FGDs were held by inviting vocational school teachers, Principal, and deputy principal curriculum areas. Based on the obtained FGD improvement suggestions input to the model. The first is the suggestion of a professor of management at the planning phase that needs to pay attention to human resources include Man, money, materials, methods, money, and machine.

Furthermore, the improvement of the management model on Industrial-Class Vocational Boarding Schools (Pesantren) to develop graduates with character and competence. After the repair of suggestions when implemented the FGD final model of management model on industrial-class vocational boarding schools to develop graduates with character and competence. Final Model of management model on industrial-class vocational boarding schools to develop graduates with character and competence is shown in Figure 5. 


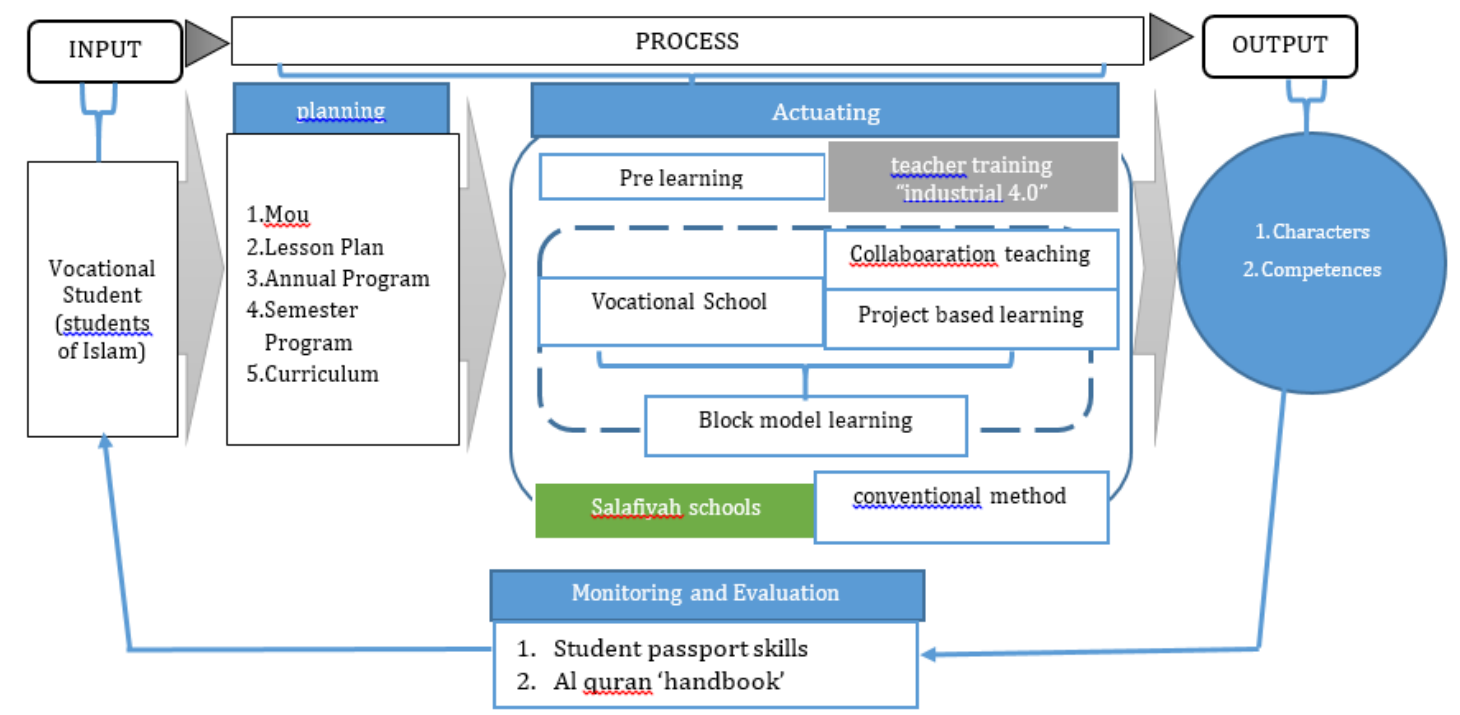

Figure 5. The final Model of management model on industrial-class vocational boarding schools (Pesantren) to develop graduates with character and competence

The final model focuses on improving the character and competence-based vocational students boarding. The characters are developed in compliance with the challenges of the industrial era 4.0. On the input is a student or students. In component, planning is still the same but the substance of the contents of a learning plan tailored to the learning objectives at the implementation phase.

During the implementation phase of the component that effecting the learning process is teachers. So that before teaching about industrial era 4.0, teachers also need to be trained first. On the final model of pre-learning to do training about industrial era 4.0 related to the opportunities and challenges for teachers at boarding school-based vocational Roudlotul Mubtadiin Balekambang, Jepara.

The next phase is learning for students. In the process of learning to use a project-based learning approach (PBL) and teaching collaboration, teaching-collaboration shown in Figure 6.

The project award is to create a robot pick n place that can be controlled using a wireless network. This collaborative learning involves teachers, professors, and industry partners. This collaboration is made possible, remembering the department of electrical engineering both on the competence of CNE and AVE is still lack of human resources on teachers.
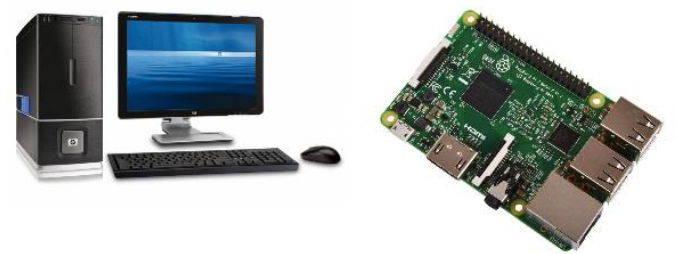

Industrial character: critical thinking; creativity and innovation; collaboration; communication 

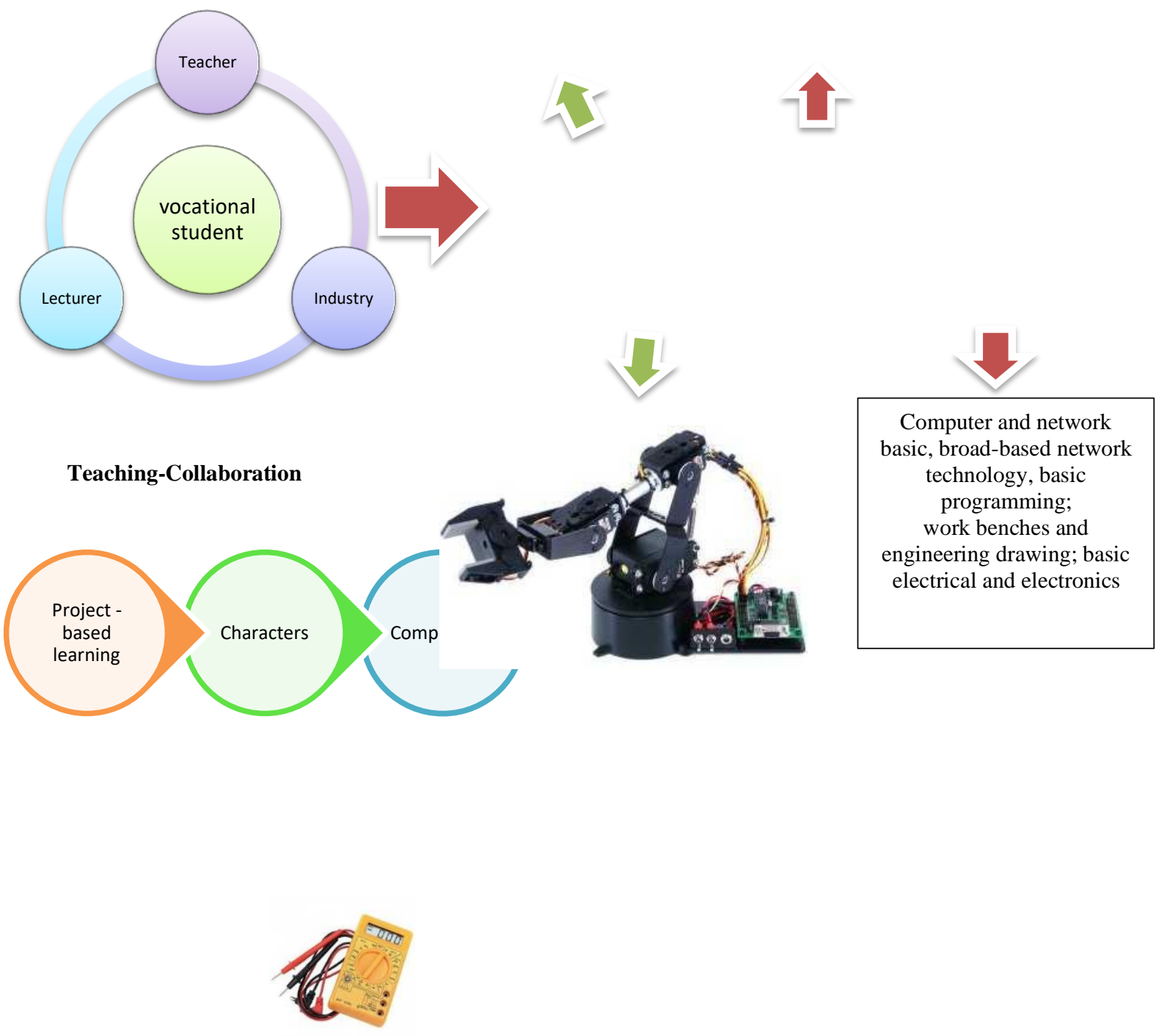

Figure 6. Teaching-collaboration model based on pesantren.

In collaborative learning, teachers-lecturers-industries together doing projects based learning. In the early phases of learning to do before the division of tasks of educators. The division of tasks for teachers and lecturers-industries are shown in Table 2. 
Table 2. Teaching-Collaboration

\begin{tabular}{cl}
\hline Human Resources (HR) & \multicolumn{1}{c}{ Materials/ Competence } \\
\hline Teacher & Computer and network basic, Broad-based network technology, Computer \\
& system \\
Lecturer & Basic programming, Basic electrical and electronics \\
Industry & Characters and Industrial competence. \\
\hline
\end{tabular}

To measure student learning outcomes assessment is required in mid and end of learning. In the mid-term test knowledge on each competency expertise with computer materials and basic network, broad-based network technology, basic programming; drawing techniques; basic electricity and electronics.

Results of the study on the knowledge aspect shown in Figure 7,8, 9.

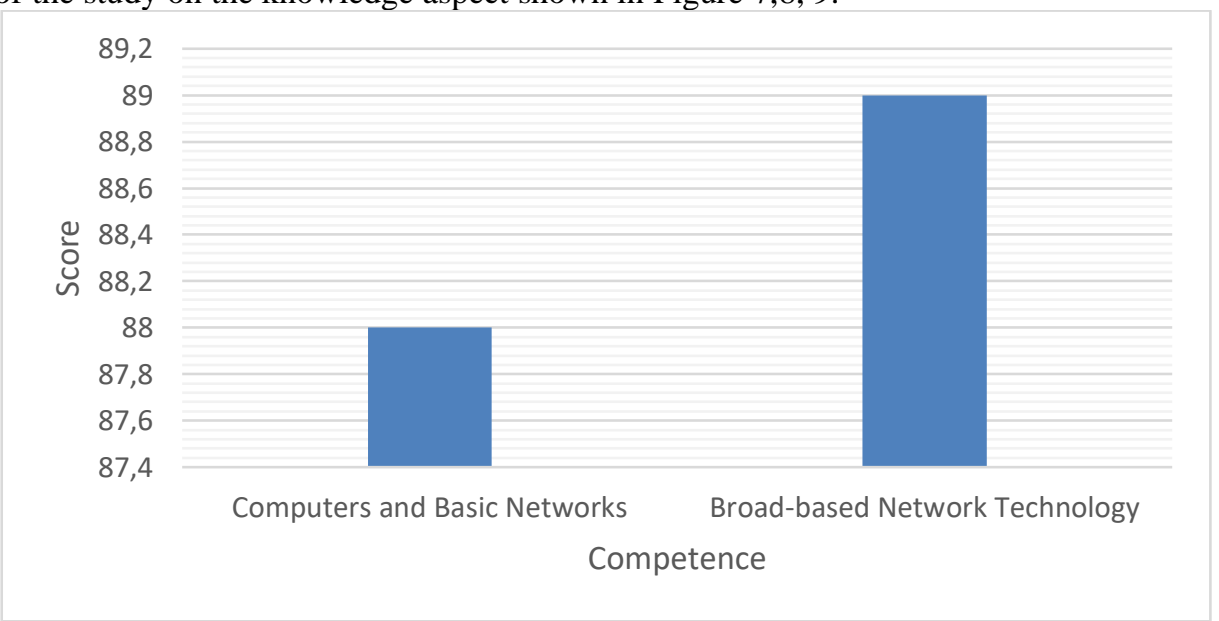

Figure 7. Competency outcome on CNE

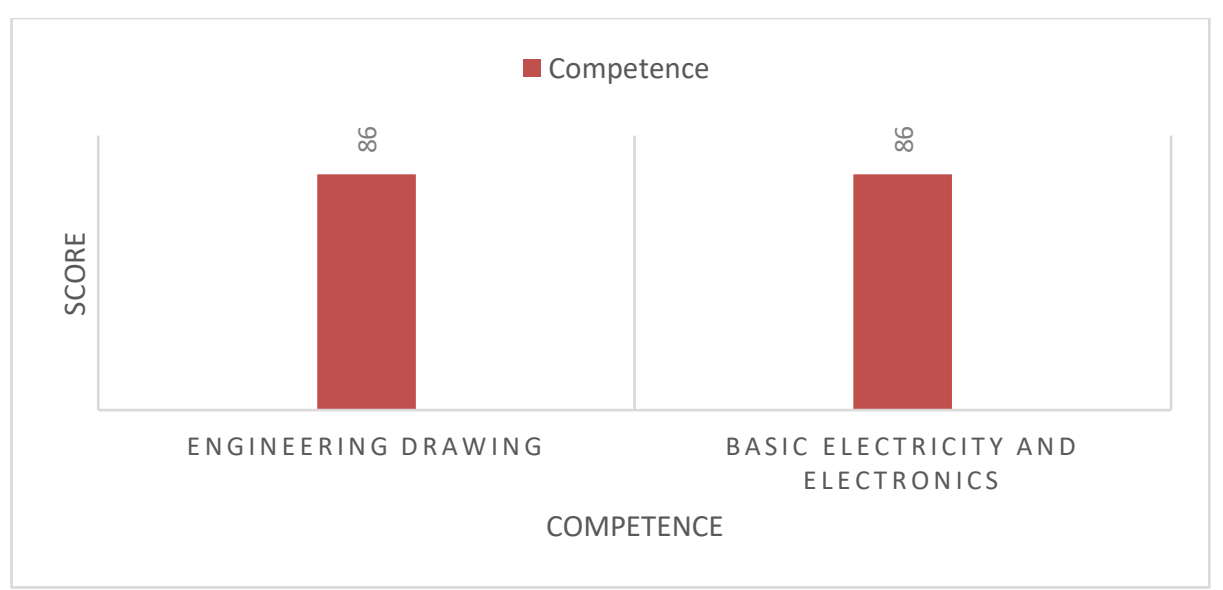

Figure 8. Competency outcome on AVE 


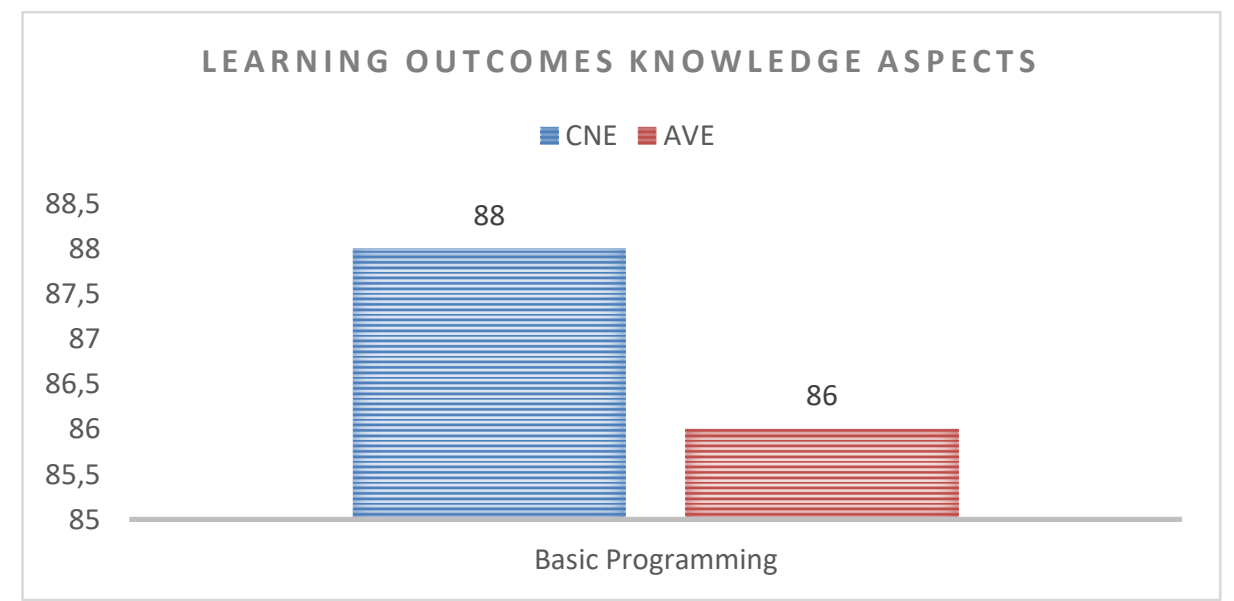

Figure 9. Results of teaching-collaboration

The results of the pre-test critical thinking skills to 88 students put into five assessment criteria, namely: excellent (91-100), good (81-90), Average (76-80), less good (70-75), and not good (<70) shows that there are many students who are still difficulties in answering the questions given with scores below 70, ie $62.5 \%$ of the 88 students. Meanwhile $25 \%$ of students scored at the range of $70-$ 75 , seven students get grades 76-80, and four students gain a good value (81-90). While critical thinking skills pre-test, there are not any students who earn grades in the range of 91-100.

After the implementation of learning about critical thinking skills in the learning period, then carried out the post-test. The results of the post-test showed that there is an increase in students' understanding of critical thinking skills. Students who scored below 70 dropped from the pre-test before learning which is 55 students being only 3 students. Increased yield significant value in the range of 81-90 score as many as 45 students from the pre-test before learning that only 4 students only, as shown in Figure 10.

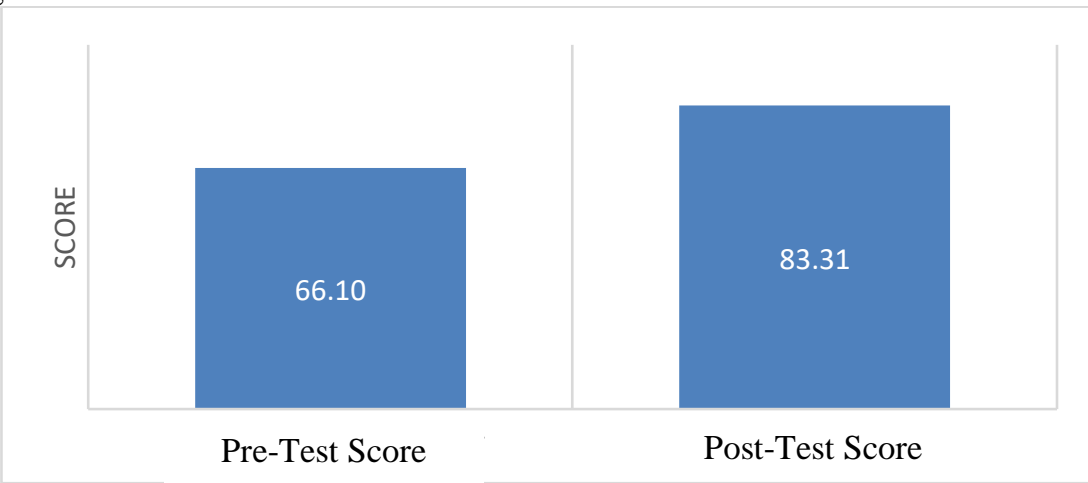

Figure 10. Increased character of critical thinking 
Overall an increase in Average yield of 88 test critical thinking skills of the student. This translates into an average increase in test scores and students' understanding of material's critical thinking skills. The Average value of the pre-test showed at 66.10 and the Average value of the posttest results is equal to 83.32, as shown in Figure 10. Thus, an increase of $21 \%$.

\section{Creative and Innovative}

Meanwhile, the results of the implementation of the pre-test creative and innovative abilities showed that 49 students (55.68\%) score below 70 out of 20 questions given. In the meantime $28.41 \%$ of students scored at the range of 70-75, 9 students scored 76-80, and four students gain a good value (81-90), and there is one student who got a very good value. after the implementation of learning about the creative and innovative abilities of students in the learning period, then carried out the post-test. The results of the post-test showed that there is an increase in students' understanding of critical thinking skills. In the post-test was not contained students who scored below 70 is inversely proportional to the pre-test before the study is 49 students. Increased yield significant value in the range of 81-90 grades of 32 students $(36.36 \%)$ of the pre-test before learning that only four students, while the remaining 25 students $(28.41 \%)$ had a value in the range of $70-75$ and 15 students $(17.05 \%)$ gets the value ranges of 76-80 and 7 students to get very good.

Overall an increase in Average yield of 88 test critical thinking skills of the student. This means an increase in the average value of the test the ability of creative and innovative students. The Average value of the pre-test showed at 67.10 and the Average value of the post-test results is equal to 80.00 . Thus an increase of $16.05 \%$, as shown in Figure 11.

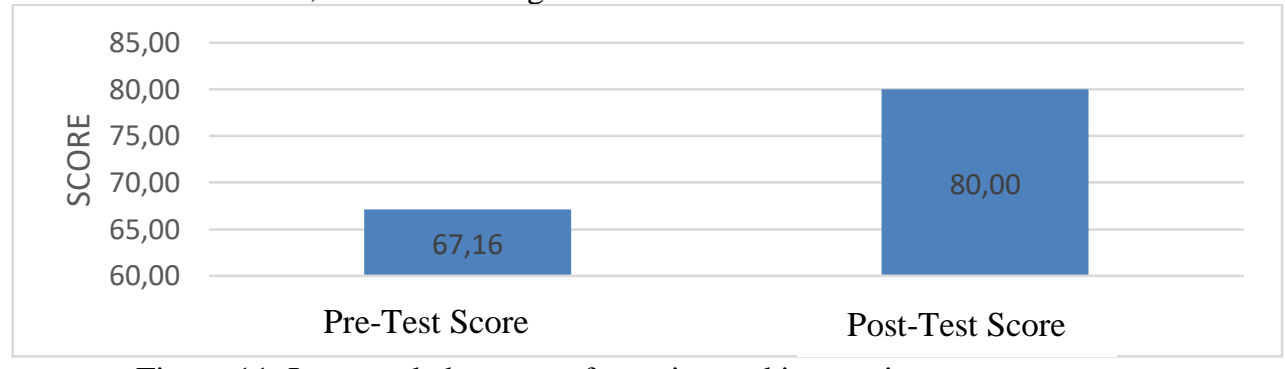

Figure 11. Increased character of creative and innovative

\section{Communication}

The results of the pre-test communication capabilities showed that 41 students $(46.59 \%)$ score below 70 out of 20 questions given. In the meantime, $37.50 \%$ of students scored at the range of 70 75,9 students $(10.23 \%)$ to get the value of $76-80$, and five students gain a good value (81-90), and there are students that scored highly good or 91-100 range.

After the implementation of learning about the communication skills of students in the learning period, then carried out the post-test. The results of the post-test showed that there is an increase in students' understanding of critical thinking skills. At post-test, there are two students who scored below 70, down significantly on the pre-test as many as 41 students. Increased yield significant value in the range of $81-90$ grades of 27 students (30.68\%) of the pre-test before learning that only 5 students only, while the remaining 30 students $(34.09 \%)$ had a value in the range of $70-75$ and 21 
students (23.86\%) gets the value ranges of 76-80 and 8 students to get very good value, as shown in Figure 12.

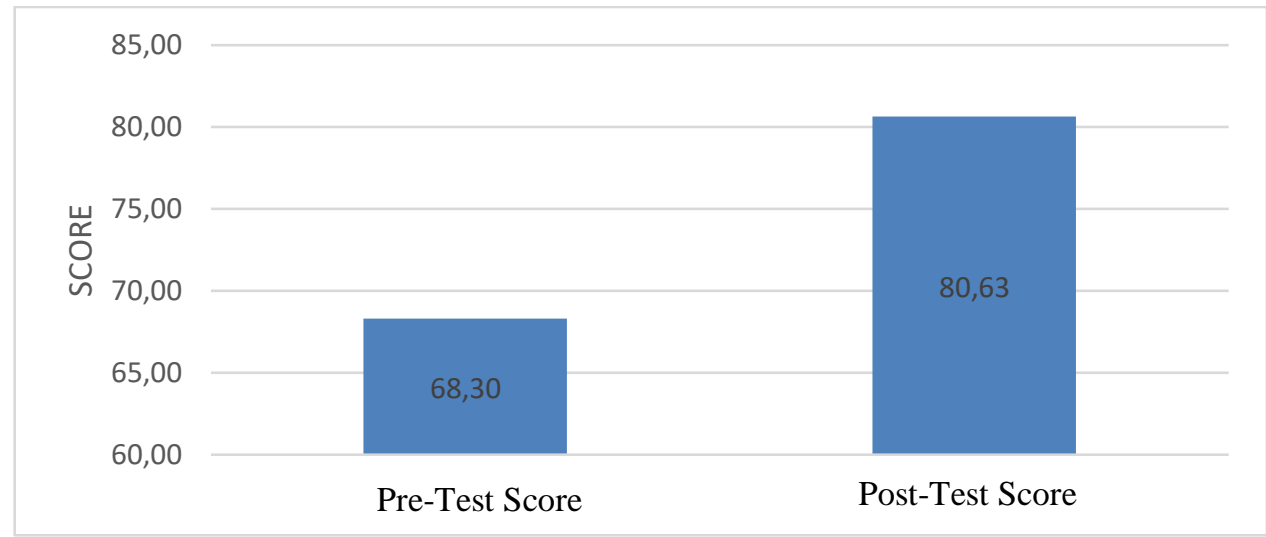

Figure 12. Increased character of communication

Based on Figure 12, overall an increase in the average yield of 88 students test the communication abilities. This means an increase in the average value of the communication ability test. The Average value of the pre-test showed at 68.30 and the Average value of the post-test results is equal to 80.63 . Thus an increase of $15.29 \%$.

\section{Collaboration}

The implementation of the pre-test capability of the collaboration showed that there was 47 students $(53.41 \%)$ score under 70 . Meanwhile, $41.91 \%$ of students scored at the range of 70-75, 3 students (3.41\%) gain grades 76-80, and two students get a good (81-90), and there are students who get very good value or range of 91-100.

After the implementation of learning about the capability of the collaboration of students in the learning period, then carried out the post-test. The results of the post-test showed that there is an increase in students' understanding of the ability to work together. At post-test, there are three students $(3.41 \%)$ who scored below 70 , down significantly from pre-test results as many as 47 students. Increased yield significant value in the range of 81-90 score as many as 43 students $(48.86 \%)$ of the pre-test before learning that only 2 students only, while the remaining 14 students $(15.91 \%)$ had a value in the range of 70-75 and 19 students (21.59\%) gets the value ranges of 76-80 and 9 students to get a very good value, as shown in Figure 13. 


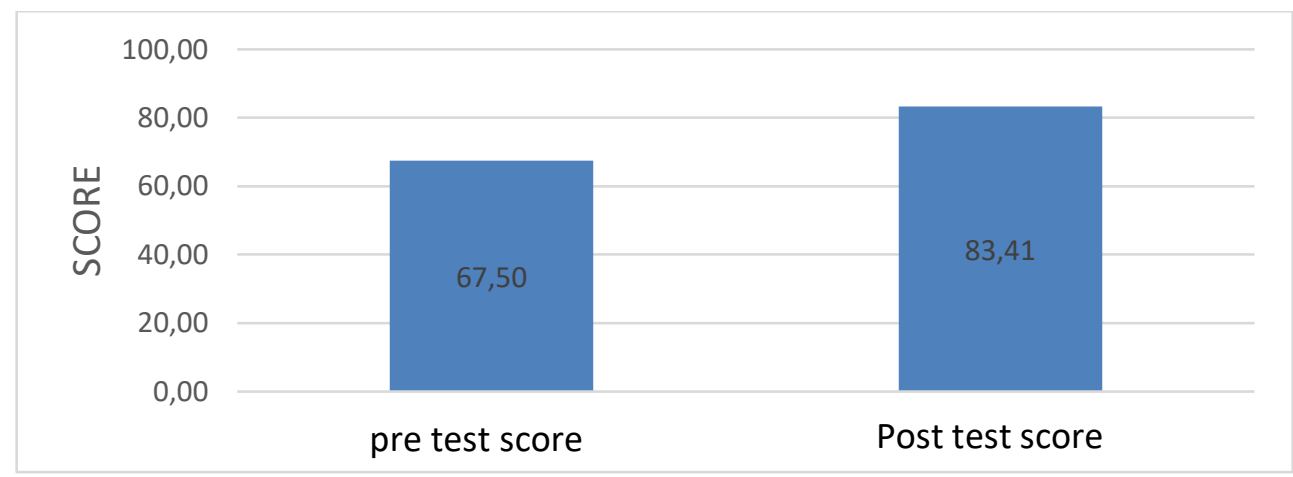

Figure 13. Increased character of collaboration

Based on the results of two tests, overall an increase in the Average results of tests the ability of the student's collaboration 88 . This means an increase in the average value of the test capability of the collaboration. The Average value of the pre-test showed at 67.50 and the Average value of the post-test results is equal to 83.41. Thus an increase of 19.07\%, as shown in Figure 13 .

\section{Conclusions}

Based on the research conclusions in this study are:

a. It has been found based industrial grade management model effective boarding school with basic learning project-based learning, collaboration and learning teaching block system to improve the character and competence of vocational students.

b. The management model based industrial grade boarding school consists of planning, implementation, monitoring, and evaluation. In planning includes the MoU, lesson planning, annual program, semester program, educational calender, and curriculum. In exercising their training program before learning teachers with industrial materials 4.0. pad learning process using project-based learning, teaching collaboration, using the block system. On the implementation of the student's study together (collaborative learning) to complete the project given. Salafiyah schools still use conventional methods of learning. Monitoring the development of students can use students' skills passport, handbooks Quran and can use the help of information technology.

c. There was an increase of characters needed in the industrial era 4.0 ie critical thinking, creative and innovative, communication, and collaboration. Improved critical thinking character the Average value of the pre-test of 66.10 and the Average value of the post-test results is equal to 83.32 , an increase of $21 \%$. Increased innovative creative character the average value of the pretest of 67.10 and the Average value of the post-test is at 80.00 an increase of $16.05 \%$. Improved communication character the Average value of the pre-test of 68.30 and the Average value of the post-test of 80.63 , an increase of $15.29 \%$. Increased collaboration character the Average value of the pre-test of 67.50 and the Average value of the post-test of 83.41, an increase of $19.07 \%$. 


\section{Recommendations for VHS based on Pesantren}

Project-based learning and teaching collaboration greatly enhance the character and competence of vocational students. Based on the research conclusions of this study include:

a. Enhancing their character vocational students,

b. Increase enhancing their competency-based vocational student's boarding,

c. The discovery of industrial-grade management model,

d. Teaching collaboration teaching in Vocational Schools where there is a lack of teachers can be implemented by making lecturers as guest teachers on required subjects.

\section{Limitation and Future research}

This research is limited to the management model applied to pesantren. A future research projectbased learning and teaching collaboration for the competence of different skills.

\section{References}

Andrews, J. and Higson, H. (2008), “Graduate employability, 'soft skills' versus 'hard' business. Bakrun. (2018). Peningkatan Proses Pembelajaran dan Penilaian Abad 21 dalam Meningkatkan Kualitas Pembelajaran SMK. Jakarta: Direktorat Pembinaan Sekolah Menengah Kejuruan dan Direktorat Jenderal Pendidikan Dasar dan Menengah Kementerian Pendidikan dan Kebudayaan.

Bukit, M. (2014). Strategi dan inovasi pendidikan kejuruan dari kompetensi ke kompetisi. Bandung: Alfabeta.

Chandra Ritu. (2015). "Collaborative Learning for Educational Achievement". Journal of Research \& Method in Education. Vol. 5, Issue 2, pp 01-04.

Deist, F.D.L., Winterton, J. (2005). "What Is Competence?" Human Res. Dev. Int. 8, 27-46/

Fiala, N., Gertler, P. and Carney, D. (2014). The role of hard and soft skills in entrepreneurial success: experimental evidence from Uganda. AEA RCT Registry, 7 November.

Gagnon, R. (2009). Competency. Meaningful Learning and Learning Styles in TVET. In R. Maclean \& D. Wilson (Eds.), International Handbook of Education for the Changing World of Work (pp. 2697-2712): Springer Netherlands.

Ganefri. (2013)."The Development of Production-Based Learning Approach to Entrepreneurial Spirit for Engineering Students'. Asian Social Science; Vol. 9 No. 12.

Hendarman, et all, (2016). Revitalisasi Pendidikan Vokasi. Jakarta, Dit PVHS.

Indonesian ministry of industry.(2018). Making Indonesia 4.0. Directorate of Vocational High School Development.

Indrawan, Eko Nizwardi Jalinus, Syahril. (2018). "Review Project Based Learning". International Journal of Science and Research (IJSR). Vol. 8 Issue 4 pp. 1014-1018.

Jones, B. and Iredale, N. (2010). "Enterprise education as pedagogy". Education + Training, Vol. 52 No. 1 , pp. 7-19. 
Kholis, Nur. (2012). Pesantren dan Pendidikan Karakter Bangsa Membangun Indonesia Yang Bermartabat, Mampukah?. Seminar Nasional Pendidikan Karakter Bangsa, Bojonegoro

Klemp, G. (1980). "The assessment of occupational competence". Report. Nat. Inst. of Edu. knowledge: a European study", Higher Education in Europe, Vol. 33 No. 4, pp. 411-422.

Leinweber S. Etappe 3 (2013): Kompetenzmanagement. In: Meifert MT, editor. Strategische Personalentwicklung - Ein Programm in acht Etappen. 3rd ed. Wiesbaden: Springer Fachmedien; pp. 145-178.

Mas'udi, M Ali. (2015). "Peran Pesantren dalam Pembentukan Karakter Bangsa". Jurnal Paradigma, Vol. 2 No. 1.

Nofiaturrahmah, Fifi. (2014). "Metode Pendidikan Karakter di Pesantren". Pendidikan Agama Islam, Vol. XI, No. 2, pp. 201-216.

Omari, Nopan. (2015). "Pentingnya Pendidikan Karakter Dalam Dunia Pendidikan". Manajer Pendidikan. Vol 9. No. 3.

Pratama, Dian Arif Noor. (2019). "Tantangan Karakter Di Era Revolusi Industri 4.0 Dalam Membentuk Kepribadian Muslim. Al-Tanzim": Jurnal Manajemen Pendidikan Vol. 03 No. 01, pp. 198-226.

Pratiwi. T. R and Muslims. (2016). "Learning IPA Integrated mode To Improve Critical Thinking Skills Junior High School Students". Indonesian Journal of Physics Education, 12 (1): pp 54-64.

Prosser, C.A. \& Quigley, T.H. (1950). Vocational Education in a Democracy. Revised Edition. Chicago: American Technical Society.

R. M. Capraro and S. W. Slough. (2009). Project-Based Learning: An Integrated Science, Technology, Engineering, and Mathematics (STEM) Approach, The Netherlands: Sense Publishers.

S. Redkar. (2012). "Teaching advanced vehicle dynamics using a project based learning (PBL) approach". Journal of STEM Education: Innovations and Research, vol. 13, no. 3, pp.17-29.

Saptono. (2011). Dimensi-dimensi Pendidikan Karakter. Jakarta: Erlangga

Saputri, air conditioning, Sajidan., Rinanto. Y. (2017). Identification of Critical Thinking Skills Students in Learning Biology Using Window Shopping. Proceedings of the National Seminar on Science Education(SNPs), 1 (1): 131-135.

Siswanto., Kaniawati, I., Suhandi, A. (2014). "Application of LearningModel Generation Arguments Using Scientific Methods To Improve Cognitive Ability and Skills Students Argue". Indonesian Journal of Physics Education, 10 (2): 104-116.

Straka, Gerald A. (2004). Measurement and evaluation of competence. Report, Cedefop

Straka, Gerald A. (2007). "Has Germany sacrificed its concept of competence at the altar of the EU?". European Journal of Vocational Training. Vol 2. No. 44.

Teng, W. and Turner, J.J. (2018), "Reflections and evaluation of Chinese enterprise education: the role of institutions from the perspective of learners", in Turner, J.J. and Mulholland, G. (Eds), International Enterprise Education: Perspectives on Theory and Practice, Routledge, London, pp. 5.

Trilling, Bernie and Charles Fadel. (2009). 21st Century Skills: Learning for Life in Our Time. San Fransisco: Jossey-Bass, A Wiley Imprint. 
Turner, J.J. and Mulholland, G. (2017). "Enterprise education: towards a framework for engaging with tomorrow's entrepreneurs". Journal of Management Development, Vol. 36 No. 6, pp. $1-18$.

Yuliati, Y. (2017). "Science Literacy in Learning IPA". Pendas Horizon Journal, Vol 3 (2): pp 2128.

Yunus, K. and Li, S. (2005), Matching Jobs Skills with Needs, Business Times, Singapore.

Zubaidah, S. (2016). “ 21st Century Skills: Skills Taught Through Learning”. State University of Malang Journal, 1 (1): 1-17

Zuhry, M. Syaifuddien. (2011). "Budaya Pesantren dan Pendidikan Karakter Pada Pondok Pesantren Salaf". Waliosongo Vol 19 No.2 hlm 287-310. 